\title{
Endangered primates in the Selous Game Reserve and an imminent threat to their habitat
}

\author{
Barbara S. Decker
}

The Magombera Forest in Tanzania contains the most viable population of the endangered Uhehe red colobus monkey, three other primates, and rare and endemic plants and animals. In 1980 almost half of the Magombera Forest Reserve was surrendered for settlement in exchange for the southern part being incorporated into the Selous Game Reserve. Due to an oversight, the southern part was not legally annexed into the Selous and now the Kilombero Sugar Company has claimed a portion of it. The forest is currently in good condition and offers the best opportunity to conserve the Uhehe red colobus. The author recommends a number of measures to save the forest and its wildlife and to ensure that the needs of the local people are met.

The Uhehe or Iringa red colobus Colobus badius gordonorum* inhabits a small geographical range in the Uzungwa Mountains and nearby lowland in southern Tanzania. This arboreal primate is restricted to scattered forest fragments and is subject to pressures from agricultural and timber activities and hunting (Rodgers and Homewood, 1982). Now endangered (Lee et al., 1988), it is listed in Appendix II of CITES and the African Convention, Class $\mathrm{A}$, which restricts or bans capture, hunting and trade, and it has the status of 'Presidential Game' in Tanzania.

The most viable population of the Uhehe red colobus inhabits the Magombera Forest at the base of the Uzungwa Mountains (Rodgers et al., 1979) and nearby riverine forests (Figure 1). The forests of the Uzungwas, like other mountains of the Eastern Arc range, are species rich and have a high number of endemic taxa. Magombera was isolated from the forested slopes of the Uzungas in recent times by roads and human settlement. Although

*The nomenclature used in this paper follows Rahm (1970) and Struhsaker (1981) for the red colobus, Dandelot (1968) for the black-and-white colobus, and Rodgers and Homewood (1982) for the Sykes' monkey. most famous for its population of red colobus, Magombera also contains three other primate species: black-and-white colobus Colobus an-golensis palliatus, Sykes' monkey Cercopithecus mitis monoides, and a species of bushbaby Galago sp. The forest is interesting for its birds, with a number of montane species occurring at an unusually low altitude (S. Stuart, per. comm.). Rare plant species and an endemic species of tree frog have already been identified (Rodgers et al., 1979), and further surveys of the flora and fauna promise to reveal other species endemic to the Eastern Arc. The forest provides refuge for at least 23 mammal species, 10 of them restricted to the forest habitat and 13 savannah mammals that also use the forest. Magombera floods during the rainy season as part of the Kilombero wetland, which provides habitat for numerous waterbirds.

\section{The threat to Magombera}

Before 1980 Magombera was an 11-sq-km forest reserve bisected by the TAZARA railway. The forest was badly damaged when the railway was built and all commercial timber was 


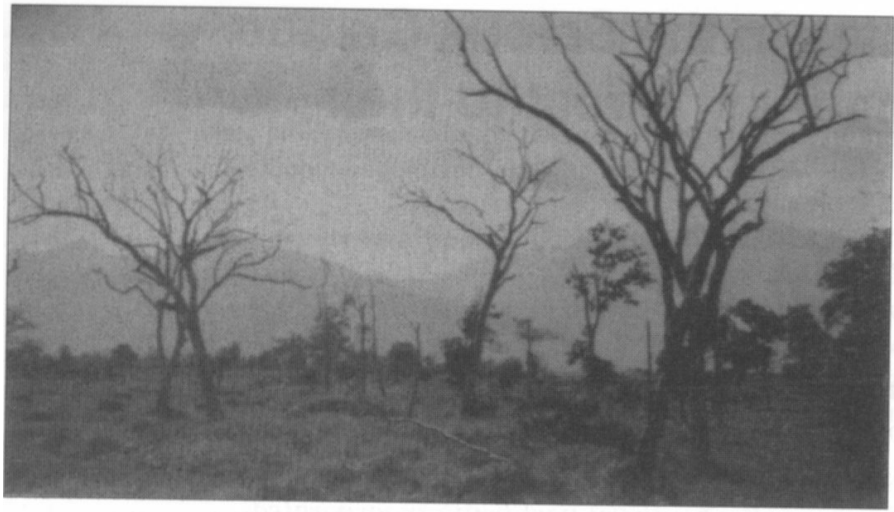

The northern segment of Magombera Forest, which was clear-cut after degazettement. The Uzungwa Mountains are in the background (H. Hertel).

removed (Rodgers and Homewood, 1982). Magombera was surrounded by settlement. Rice cultivation extended into gaps and along stream-banks in the forest, and poaching of game and timber was rife (Rodgers et al., 1979).
In 1980 Tanzanian government authorities agreed to include the southern portion of Magombera Forest Reserve in the Selous Game Reserve in exchange for Selous Game Reserve land and the portion of Magombera

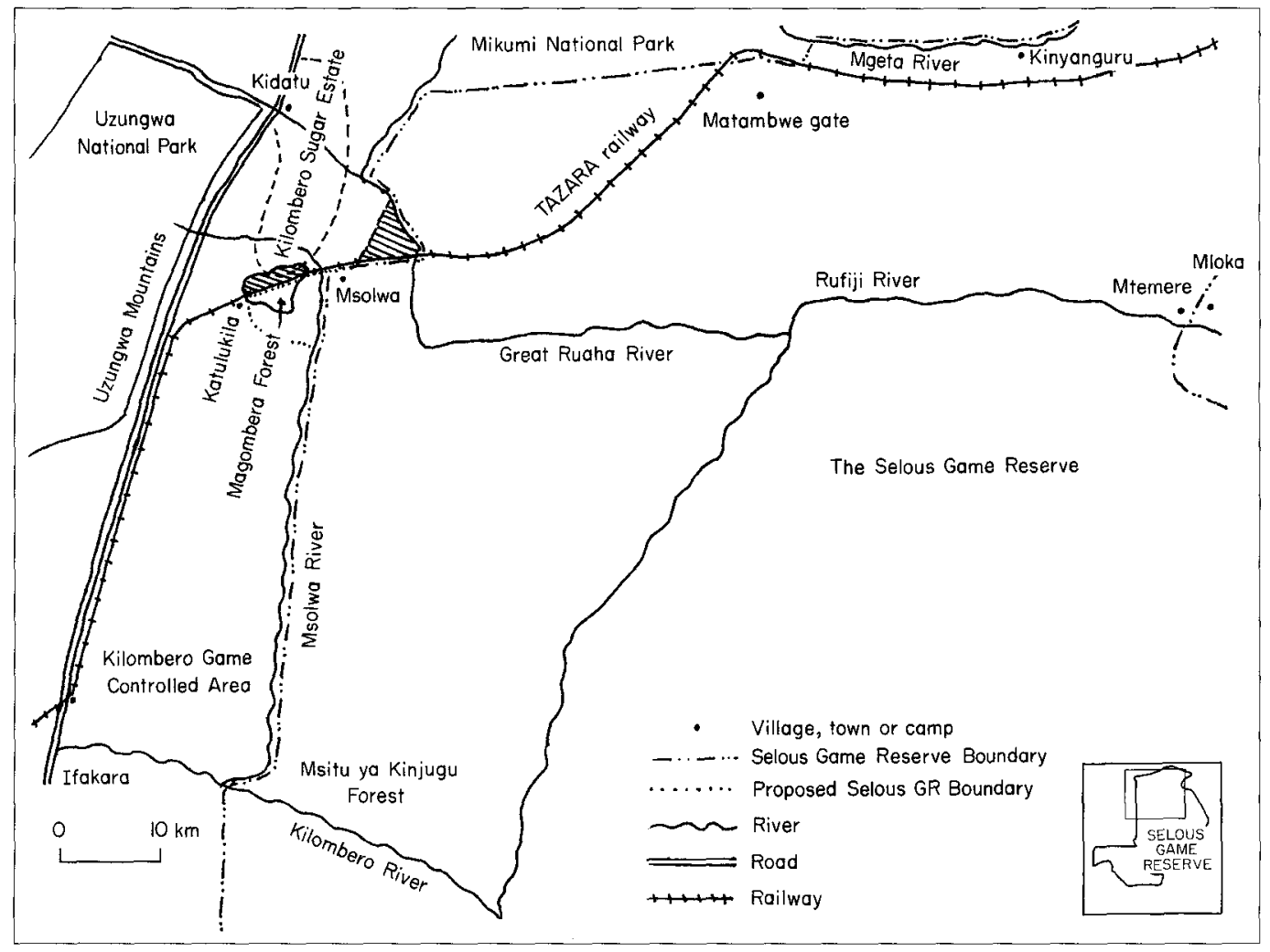

Figure 1. Map showing localities referred to in the text. The diagonally hatched areas were degazetted from the Selous GR and Magombera FR in 1980 in exchange for annexation into the Selous GR of the southern part of Magombera Forest. The annexation was never legally formalized and is now contested. Inset: map of the Selous GR indicating enlarged area. 
Forest Reserve north of the TAZARA railway (Bigurube and Baldus, 1992). In this exchange, approximately $31 \mathrm{sq} \mathrm{km}$ of the Selous was given to the Kilombero Sugar Estate for settlement (Kirenga, 1992) (Figure 1). In addition, people who had been living south of the railway around Magombera Forest were resettled in the $5-\mathrm{sq}-\mathrm{km}$ northern segment of the Magombera Forest Reserve, which they cleared and planted with rice. This part of Magombera Forest contained an estimated 150 red colobus monkeys (Rodgers et al., 1979). Due to an oversight, which was not discovered until 1992, the remaining $6 \mathrm{sq} \mathrm{km}$ of Magombera south of the railway was never legally annexed into the Selous. Until the annexation is formalized, the forest is not legally protected, and the Kilombero Sugar Company has claimed a portion of it. The disputed area is unsuitable for cane sugar but could be clearcut to provide a small amount of fuel for the wood-powered sugar refinery.

\section{Census of Magombera}

\section{Methods}

A census was conducted during the dry season from September to November 1992 in order to obtain information on the Magombera primate populations and on the condition of the forest. Twenty north-south transects, totalling an estimated $31 \mathrm{~km}$, were covered during $63 \mathrm{~h}$ in the forest. Another $21 \mathrm{~h}$ were spent on census walks along the railway, totalling about $43 \mathrm{~km}$. Numbered telegraph poles spaced $50 \mathrm{~m}$ apart along the railway enabled accurate positioning of transects and were used to assign an identification number to each primate group. Any diversions from the transects were mapped using a stopwatch and compass and an estimated walking speed. Visibility in the forest canopy was generally $100 \mathrm{~m}$. The locations of all primates seen were mapped and the number of individuals and age/sex composition of all colobus groups were recorded when possible. Determination of age categories followed the method used in censusing Tana River red colobus Colobus

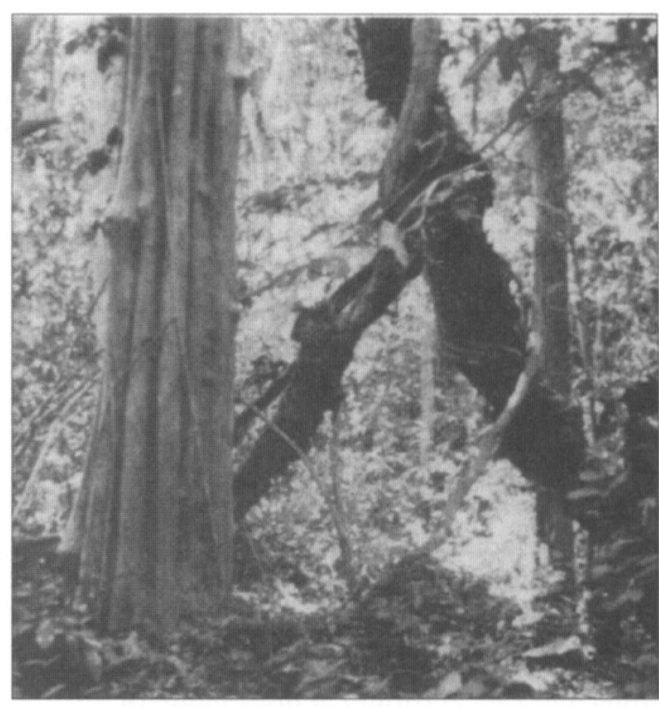

The interior of Magombera Forest (H. Hertel).

badius rufomitratus in terms of differences in size and coloration (Decker, 1989). Statistical tests exclude groups No. 1812 and No. 1858. Although complete counts were obtained of total individuals in those groups, a number of the animals were not identified by age and gender.

\section{Results}

Sixteen groups of red colobus, nine groups of black-and-white colobus and 14 groups of Sykes' monkeys were seen. Population parameters for the three species are given in Table 1. Red colobus and black-and-white colobus are evenly distributed throughout the forest, but Sykes' monkeys were seldom seen in the forest interior. Red colobus groups for which complete counts were obtained ranged in size from 26 to 50 individuals $(\bar{x}=34)$ (Table 2). Groups of black-and-white colobus varied in size from 5 to 9 individuals $(\bar{x}=6)$ (Table 2). The total number of individuals of each species was estimated by multiplying the number of groups seen by the mean group size obtained from complete counts (Table 1).

Other mammals seen, heard or whose spoor was identified were elephant, buffalo, leopard, zebra, waterbuck, impala, hippo, bush pig, 
Table 1. Magombera primate population parameters

\begin{tabular}{lllll}
\hline & $\begin{array}{l}\text { Red } \\
\text { colobus }\end{array}$ & $\begin{array}{l}\text { Black-and- } \\
\text { white colobus }\end{array}$ & $\begin{array}{l}\text { Sykes' } \\
\text { monkey }\end{array}$ & Total \\
\hline No. groups & 16 & 9 & 14 & 39 \\
Mean group size & 34 & 6 & $10^{*}$ & - \\
Range of complete counts & $26-50$ & $5-9$ & - & - \\
No. individuals counted & 338 & 46 & - & - \\
No. individuals estimated & 544 & 54 & 2.3 & 738 \\
Group density/sq km & 2.7 & 1.5 & 23.3 & 123 \\
Arimal density/sq km & 90.7 & 9.0 & - & - \\
Per cent infants and juveniles & 38.7 & 19 & & \\
Ratios & & & & \\
Adult male: adult female & 0.13 & 1.10 & 0.27 & \\
Infants: adult females & 0.51 & 0.80 & & \\
All immatures: adult females & 0.87 & & & \\
\hline
\end{tabular}

* Estimated

Table 2. Magombera colobus group composition from complete counts only

\begin{tabular}{|c|c|c|c|c|c|c|c|c|c|}
\hline Group no. & $\mathrm{AM}$ & $\mathrm{AF}$ & SA & LJ & SJ & LI & CI & UI & Total \\
\hline \multicolumn{10}{|c|}{ Red colobus } \\
\hline 1807 & 1 & 13 & 3 & 5 & 2 & 0 & 9 & 1 & 34 \\
\hline 1812 & - & 5 & - & 1 & 3 & - & 5 & 36 & 50 \\
\hline 1829 & 1 & 9 & 0 & 1 & 4 & 2 & 6 & 5 & 28 \\
\hline 1833 & 2 & 14 & 2 & 3 & 0 & 0 & 10 & 0 & 31 \\
\hline 1839 & 3 & 11 & 2 & 1 & 1 & 1 & 6 & 1 & 26 \\
\hline 1847 & 2 & 26 & 2 & 5 & 4 & 0 & 3 & 0 & 42 \\
\hline 1858 & 2 & 11 & 0 & 0 & 3 & 0 & 8 & 12 & 36 \\
\hline 1873 & 2 & 11 & 1 & 2 & 2 & 0 & 6 & 3 & 27 \\
\hline Totais & 13 & 100 & 10 & 18 & 19 & 3 & 53 & 58 & 274 \\
\hline Mean* & 1.8 & 14 & 1.7 & 2.8 & 2.2 & 0.5 & 6.7 & 1.8 & 31.5 \\
\hline Mean $(\%)$ & 5.7 & 44.4 & 5.4 & 8.9 & 7.0 & 1.6 & 21.3 & 5.7 & 100 \\
\hline \multicolumn{10}{|c|}{ Black-and-white colobus } \\
\hline 1829 & 1 & - & 2 & 1 & - & - & - & $3 \mathrm{~A}$ & 7 \\
\hline 1833 & 3 & 2 & - & - & - & - & - & - & 5 \\
\hline 1839 & 2 & 2 & - & - & 2 & - & - & - & 6 \\
\hline $1872 a$ & 2 & 3 & 1 & - & 1 & 1 & - & 1 & 9 \\
\hline $1872 b$ & 1 & 1 & - & - & - & - & - & 3 & 5 \\
\hline 1895 & 1 & 1 & - & 1 & - & - & 1 & 1 & 5 \\
\hline Totals & 10 & 9 & 3 & 2 & 3 & 1 & 1 & 8 & 37 \\
\hline Mean & 1.7 & 1.5 & 0.5 & 0.3 & 0.5 & 0.2 & 0.2 & 1.3 & 6.2 \\
\hline Mean (\%) & 27.4 & 24 & 8 & 4.8 & 8 & 3.2 & 3.2 & 21 & 100 \\
\hline
\end{tabular}

AM, adult male; AF, adult female; SA, subadult; LJ, large juvenile; SI, small juvenile; LI, large infant; CI, small, clinging infant; $U I$, unidentified individual; $A$, adult.

${ }^{*}$ Means exclude Nos. 1812 and 1858 (see text). 
warthog, suni, duiker, porcupine, bushbuck, bushbabies, baboons, hyena, genet, banded mongoose, squirrel and crocodile. The savannah mammals used the forest in the dry season, with elephants and buffalo encountered even in the interior along a perennial stream, and sought refuge there from the widespread bushfires.

\section{Censuses of other forests in the Selous}

Primate censuses were conducted in a number of other forests in the Selous where either red colobus had been reported or where habitat appeared suitable for them. Near Magombera, these included (i) forests along the Great Ruaha River, (ii) riverine forests along the Msolwa River from the railway south to the confluence with the Kilombero River including Msitu ya Kinjugu, and (iii) a forest patch on the railway east of Msolwa Ranger Station. Other areas surveyed encompassed (i) the track from the western gate near Kitadu through miombo woodland to Matambwe gate, (ii) forests near the eastern gate of Mtemere and Mloka village, and (iii) riverine forests along the Mgeta River near Kinyanguru.

Red colobus were discovered in Kiwanga forest, a small patch east of Magombera and connected to it by a shrub corridor, and in a forest patch just east of Msolwa Ranger Station. A survey along the Msolwa River south of the railway to the confluence with the Kilombero River, a distance of $50 \mathrm{~km}$, revealed four groups of red colobus in the riverine forest and in the large Msitu ya Kinjugu. Red colobus had not been recorded previously in these forests. Black-and-white colobus and Sykes' monkeys were also seen in all these locations.

Black-and-white colobus and Sykes' monkeys were also observed in the riverine forests along the Great Ruaha River inside the Selous Game Reserve near Msolwa. Investigations into reported sightings of colobus monkeys across the entire Selous to Mloka did not reveal any red colobus but verified the existence of back-and-white colobus along the Mgeta
River near Kinyanguru, in two locations near Mloka, and in miombo woodland near the northern Selous border with Mikumi National Park.

\section{Discussion}

In 1980, believing that the forest and surrounding area had been gazetted into the Selous, the local people living and farming around Magombera Forest moved north of the railway. Since then the Selous Sector Manager and game scouts at Msolwa have done an excellent job of protecting the forest from encroachment. The forest is in far better condition than when described by Rodgers et al. (1979). Regeneration is vigorous and few signs were seen of encroachment for wood products. However, the annual raging bushfires within the reserve and the Kilombero Game Controlled Area severely burn forest edges and probably account for the lack of secondary growth on the perimeter of all the forests. I was told that these fires are started by professional hunters and illegal gatherers of wood products to clear the high grass for improved visibility. Burning also occurs regularly along the railway tracks: this is started both by passing trains and human activity. We confiscated several buffalo and guinea fowl snares in the western and south-western parts of Magombera Forest near the village of Katulukila and witnessed illegal gathering of Phoenix reclinata palm fronds on the southern side. Although elephants were encountered in every part of the forest, damage to vegetation from these animals appeared minimal.

The Magombera red colobus population may offer the best, possibly the only, opportunity to save the subspecies. Uhehe red colobus also inhabit forest patches in the Uzungwa Mountains, but their patchy distribution inhibits or prevents movement of animals and decreases genetic viability (Rodgers and Homewood, 1982). The exact size and distribution of these populations is unknown. In the geographical range of this subspecies, only the new Uzungwa National Park affords adequate legal protection. The other populations 
inhabit forest reserves and unprotected areas in the Uzungwas, all of which are subject to timber activities and other forms of exploitation. Primate density in the higher elevations is reportedly very low (Rodgers and Homewood, 1982). The size and steep slopes of Uzungwa National Park inhibit frequent and widespread patrolling. The red colobus populations in the mountains are subject to hunting pressure by the Wahehe people (Rodgers and Homewood, 1982) for whom they are a preferred source of protein (S. Wasser, pers. comm.). At the base of the mountains, in the predominantly Muslim communities near Magombera, little or no hunting occurs. The genetic viability of Magombera's red colobus population is enhanced by the concentration of over 500 individuals in one forest with no barriers to transfer between groups. After investigating possible transfer corridors between the main forest and Kiwanga and the riverine forests along the Msolwa, it appeared that transfer is possible but probably difficult and infrequent for the very arboreal and shy red colobus. Therefore, any further loss of forest area in Magombera could render the colobus populations non-viable.

Population parameters for the Magombera red colobus indicate relatively good recruitment into the adult class and a fairly healthy population. The percentage of juveniles and infants was 38.7 per cent, comparable with the findings of a 1977 study, which reported group composition of 38.4 per cent infants and juveniles (Struhsaker and Leland, 1980). However, there is a significant difference in overall age structure both between the 1992 and 1977 (Struhsaker and Leland, 1980) group compositions $\left(\chi^{2}=23.36, \mathrm{df}=6, P<0.005\right)$ and between 1992 and group compositions of 1977 and 1979 combined (Rodgers et al., 1980) $\left(\chi^{2}=\right.$ $46, \mathrm{df}=5, P<0.005)$. In 1992 there were fewer subadults, large juveniles and adult males and more adult females and clinging infants.

The black-and-white colobus may not be as viable, with only one clinging infant seen and only 19 per cent of the population in the juvenile and infant classes. Black-and-white colobus at other sites are known to prefer sec- ondary growth usually found in abundance on the forest edges and in gaps (Struhsaker and Oates, 1975). The fact that this type of vegetation has been removed or burned from the edge of Magombera and that many forest gaps have regenerated may be negatively impacting the black-and-white colobus.

A 1979 census estimated that there were 34 groups of black-and-white colobus and 42 groups of Sykes' monkeys in Magombera, based on extrapolation from censuses along the railway tracks (Rodgers et al., 1980). The sightings of nine groups of black-and-white colobus and 14 groups of Sykes' monkeys in this survey may indicate decreases in populations of these two species or may reflect different census methods. A possible preference of both of these species for forest edge habitat may have caused an overestimation of the number of groups in the 1979 census (Rodgers et al., 1979). The average size of the black-andwhite colobus groups was the same in both censuses.

The 1979 census (Rodgers et al., 1980) estimated that 150 of the 450 red colobus in Magombera inhabited the northern segment of the forest. With an estimated 472 individuals now in the southern portion, one could speculate that the northern red colobus were able to cross the railway to the safety of the southern portion when their habitat was gradually destroyed. Neither the red colobus population density at $90.7 / \mathrm{sq} \mathrm{km}$ nor the total primate population density of $123 / \mathrm{sq} \mathrm{km}$ (Table 1) is excessively high.

\section{Recommendations}

The immediate annexation of Magombera Forest into the Selous Game Reserve should be expedited by revival of the 1980 plan. It is obvious that the presumed annexation of the Magombera area into the Selous Game Reserve has already protected it from encroachment and extraction of wood products. However, a number of factors present threats to the forest and the contiguous Kilombero Game Controlled Area (KGCA): (i) patrolling and antipoaching activities in large forests or 
wetlands, which must be covered on foot, are especially difficult; (ii) legitimate needs for land and timber by industry and for wood products for house-building and household use must be met; (iii) new settlement near forests and other protected areas increases the likelihood of illegal harvesting of animals and plants; (iv) bush fires impede forest expansion.

Pressure on the forests could be alleviated by the following actions.

1. The Kilombero Sugar Factory should embark on an afforestation programme to meet its fuel requirements or should convert the factory to another fuel source. Funding is now being sought for conversion.

2. The demand for wood products by local inhabitants could be alleviated by the introduction of the following measures.

(a) Planting of wood-lots on village land and/or in a buffer zone between the village and the forest. To ensure successful germination and growth, agroforesters should be employed to organize and supervise a tree nursery, planting out and management of wood-lots. Tree species planted near the forest should be indigenous to prevent invasion of the forest by exotic species and should be species preferred by the local people.

(b) Recruitment of a council of village elders as 'Conservators' of the buffer zone wood-lots with the power to dictate who cuts what and when for personal needs.

(c) Incentives to villagers to plant trees for their personal needs on their farms. One successful project in Moshi, Tanzania pays a cash incentive directly to the farmer.

3. A fire break around the forest could be established by cutting a $10-\mathrm{m}$-wide swath about $50 \mathrm{~m}$ outside the forest edge to allow forest expansion. On the northern side, a string of ponds created by the construction of the railway retains water throughout the dry season. The creation of ditches connecting the ponds along the entire length of the forest would deter fire and human encroachment into the forest.

4. The regular presence of scientists in a reserve can deter encroachment and poaching. The Uhehe red colobus was given the highest conservation priority rating by the International

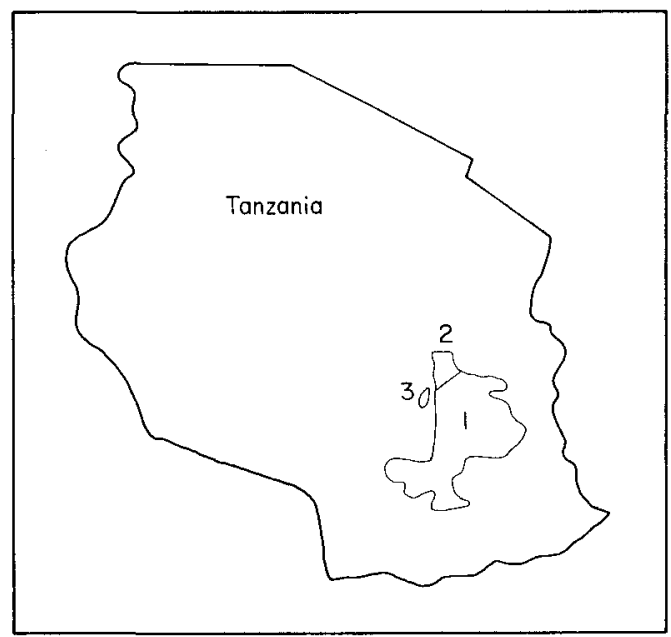

Figure 2. Map of Tanzania showing: 1, Selous Game Reserve; 2, Mikumi NP; 3, Uzungwa NP.

Primatological Society (IPS, 1990), and the IUCN/SSC Action Plan for African Primate Conservation (Oates, 1986) recommends management assistance for the Magombera area and the support of research on the primate community. The establishment of a research camp would provide the infrastructure for long-term studies of the Uhehe red colobus, whose behavioural ecology is unknown, forest dynamics, and thorough surveys of other fauna and flora.

5. Awareness of the conservation importance of Magombera would be increased by the promotion of eco-tourism. Because of its high biodiversity and its attractive birds and mammals, Magombera Forest has a high potential for specialized nature tourism. With the establishment of the nearby Uzungwa National Park (Figure 2), this area of the Selous fits well into a spectacular Southern. Circuit for wildlife tourism including Mikumi and Ruaha National Park. A management plan to provide tourist facilities and an easier, more attractive access to the forest should be developed.

6. A buffer zone of about $200 \mathrm{sq} \mathrm{km}$ inside the Kilombero Game Controlled Area has been proposed to meet the demands from industry and subsistence agriculture for land and fuelwood (Kirenga, 1992). Although the rest of KGCA will remain a wildlife management 
area, it will be difficult to patrol regularly in order to prevent illegal harvesting of wood products from the riverine forests along the Msolwa River. The protection of the red colobus in these forests should be carefully considered in any decisions with regard to the KGCA.

The Selous Conservation Programme (SCP) is currently working toward the annexation of Magombera Forest into the Selous Game Reserve. If successful, SCP will expand its buffer zone programme to include the area around Magombera. This would provide benefits to nearby villages through the sustainable use of natural resources, such as game, trees and fish, in the buffer zone.

\section{Acknowledgments}

I thank G. Bigurube, Project Manager of the Selous Conservation Programme and G. Sabuni of the Tanzania Commission for Science and Technology for permission to conduct this study. I also acknowledge R. Baldus, GTZ Co-ordinator, for his commitment to the protection of Magombera. J. Saidia, Game Scout, and H. Hertel of GTZ provided excellent assistance and companionship in the field. $\mathrm{H}$. Hertel helped greatly with map work and photography. I am grateful for the hospitality and help of R. Massawe, Selous Sector Manager, and G. Ijumba at Msolwa, Mr Minja of Intercon Hunters and Safaris at Kinyanguru, Mr Minja at Matambwe, and D. Ommanney of Mbuyu Camp, as well as Game Scouts, M. Simba, A. Ngomalufu and S. Debwe. F. Decker and Gauff Ingenieure helped immensely with logistical support. I thank C. Mabula and T. Msangi of the TAFORI Lushoto Herbarium for assistance in the identification of plant specimens. I am also very grateful to the gracious Tanzanian people, especially those of Msolwa, Mloka, and Katulukila.

\section{References}

Bigirube, G. and Baldus, R. 1992. A confidential report to the Director of Wildlife about the need to annex the Magombera Forest to the Selous Game Reserve. Selous Conservation Programme, Dar es Salaam, unpubl. report.

Dandelot, P. 1968. The Primates. Preliminary
Identification Manual for African Mammals. Smithsonian Institution, Washington, DC.

Decker, B.S. 1989. Effects of Habitat Disturbance on the Behavioural Ecology and Demographics of the Tana River red colobus Colobus badius rufomitratus. PhD Thesis, Emory University.

IPS. 1990. International Primatological Society Conservation priority projects list 1990-1992. IPS News, 17, 8 .

Kirenga, E.J. 1992. The existing land use situation in and around the Kilombero Game Controlled Area and the Selous Game Reserve. Regional Land Survey Office, Morogoro, unpubl. report.

Lee, P.C., Thornback, J. and Bennett, E.L. 1988. Threatened Primates of Africa: The IUCN Red Data Book. IUCN, Gland, Switzerland.

Oates, J.F. 1986. IUCN/SSC Primate Specialist Group Action Plan for African Primate Conservation 1986-90. IUCN/UNEP/WWF.

Rahm, U.H. 1970. Ecology, zoogeography and systematics of some East African forest monkeys. In Old World Monkeys (eds. T. H. Napier and P. H. Napier), pp. 589-626. Academic Press, London.

Rodgers, W.A and Homewood, K.M. 1982. Biological values and conservation prospects for the forests and primate populations of the Uzungwa Mountains, Tanzania. Biol. Conserv. 24, 285-304.

Rodgers, W.A. Homewood, K.M. and Hall, J.B. 1979. An ecological survey of Magombera Forest Reserve, Kilombero District, Tanzania. University of Dar es Salaam, unpubl. report.

Rodgers, W.A., Homewood, K.M., and Hall, J.B. 1980. The railway and a rare colobus monkey. Oryx, 15, 491-495.

Struhsaker, T.T. 1981. Vocalizations, phylogeny and palaeogeography of red colobus monkeys (Colobus badius). Afr. J. Ecol. 19, 265-283.

Struhsaker, T.T. and Leland, L. 1980. Observations on two rare and endangered populations of red colobus monkeys in East Africa: Colobus badius gordonorum and Colobus badius kirkii. Afr. J. Ecol. 18, 191-216.

Struhsaker, T.T. and Oates, J.F. 1975. Comparison of the behavior and ecology of red colobus and black-and-white colobus monkeys in Uganda: a summary. In Socioecology and Psychology of Primates (ed. R. H. Tuttle), pp. 103-123. Mouton Publishers, The Hague.

Barbara S. Decker, c/o Gauff Ingenieure. PO Box 152, Mombo, Tanzania and 236 Big Canoe, Big Canoe, GA 30143, USA. 